WellBeing International

WBI Studies Repository

2-25-1982

\title{
Predation by Wild Coyotes: Behavioral and Ecological Analyses
}

Michael C. Wells

University of Colorado

Marc Bekoff

University of Colorado

Follow this and additional works at: https://www.wellbeingintlstudiesrepository.org/acwp_ena

Part of the Animal Studies Commons, Behavior and Ethology Commons, and the Comparative Psychology Commons

\section{Recommended Citation}

Wells, M. C., \& Bekoff, M. (1982). Predation by wild coyotes: behavioral and ecological analyses. Journal of Mammalogy, 63(1), 118-127.

This material is brought to you for free and open access by WellBeing International. It has been accepted for inclusion by an authorized administrator of the WBI Studies Repository. For more information, please contact wbisr-info@wellbeingintl.org.

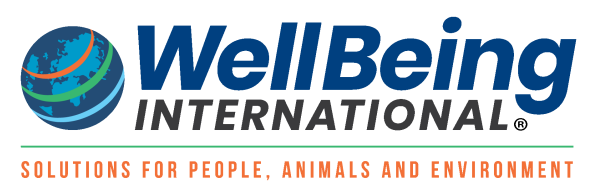




\title{
Predation by Wild Coyotes: Behavioral and Ecological Analyses
}

Michael C. Wells and Marc Bekoff

University of Colorado

\begin{abstract}
$\underline{\text { ABSTRACT }}$
Predatory behavior of coyotes (Canis latrans) was studied between 1977 and 1980 in the Grand Teton National Park, Jackson, Wyoming. Major prey were voles (Microtus spp.), Uinta ground squirrels (Spermophilus armatus), pocket gophers (Thomomys talpoides), and grasshoppers (Locustidae). Coyotes typically rushed and ran down squirrels; when hunting mice, coyotes pounced and stabbed at them with their forepaws. Sequence structure was similar, though sequences directed to squirrels were significantly more variable. When juvenile coyotes hunted mice, sequences were similar to those performed by adults that hunted mice. Adults and juveniles were about equally successful. The size of prey last eaten influenced the interval until the next search was initiated; the larger the prey, the longer the interval. However, the time interval since the last capture and the outcome (capture or failure) of the next predatory attempt were not correlated. Durations of search, orient, and stalk were longer in short $(<10$ em) grass than in tall grass; stalk, orient, and total durations also were more variable in short grass. Coyotes that hunted in short grass were more successful. Durations of all acts were shorter and coyotes were more successful in snow less than $10 \mathrm{~cm}$ deep than in deeper snow. Mean orient and total durations were more variable in deep snow. Height of ground-cover apparently affected coyote movements and the way in which cues from prey were perceived. Local wind conditions did not affect capture success. Coyotes were least successful when they hunted mice and more successful when they hunted squirrels. More time was spent searching and stalking squirrels.
\end{abstract}

Comparative studies of hunting methods have provided insights into the ecology of foraging (Tinbergen, 1960; Gibb, 1962; Holling, 1965, 1966; Schoener, 1971; Krebs, 1973; Kruuk, 1978; Dunstone and O'Connor, 1979a, b; Morse, 1980; Kamil and Seargent, 1981) and information concerning behavioral patterns used in predation (Leyhausen, 1965; Ewer, 1968; Fox, 1969; Eisenberg and Leyhausen, 1972; Rasa, 1973; Curio, 1976; Rowe-Rowe, 1978; Vincent and Bekoff, 1978; Wells, 1978; Wells and Lehner, 1978; Henry, 1980; Macdonald, 1980). Because predation by wild carnivores often is difficult to observe in detail in the field, especially when prey species are small (Kruuk, 1978; Macdonald, 1980), more is known about predation on large ungulates (Estes and Goddard, 1967; Mech, 1970; Kruuk, 1972a; Schaller, 1972; Ewer, 1973; Elliott et al., 1977). However, for many species, including coyotes (Canis latrans), major prey items are small $(<1 \mathrm{~kg}$ ) (Gier, 1968; Bekoff, 1977a). Furthermore, results of numerous studies of coyote food habits are available (Bekoff, 1977a), but only general accounts of observed predation exist for wild animals, and these mostly involve coyote-ungulate encounters (Murie, 1940; Young and Jackson, 1951; MacConnell-Yount and Smith, 1978; Truett, 1979). Thus, there is need for detailed analyses of the manner in which free-ranging coyotes hunt small prey and factors that influence predatory behavior. 
The purpose of this study was to analyze predation by free-ranging coyotes on common small prey species, such as voles (Microtus spp.), Uinta ground squirrels (Spermophilus armatus), pocket gophers (Thomomys talpoides), and grasshoppers (Locustidae). On our study area, large ungulates were represented in coyotes' diets predominantly as carrion (Murie, 1951; Weaver, 1977), and predation on a large ungulate (a pronghorn (Antilocapra americana) infant) was observed only once during the course of study. Predation was viewed as a three-part series of events comprised of prey detection, capture, and consumption. Within this framework, the following questions were considered: (1) What are the behavioral components of predatory behavior? (2) How are these components organized into hunting sequences? (3) How do age, hunger, prey species, wind conditions, and habitat (grass height, snow depth) influence predatory sequences and capture success?

\section{METHODS AND STUDY AREA}

Coyotes were observed directly for $628 \mathrm{~h}$ between September 1977 and August 1980 near the Blacktail Butte area in the Grand Teton National Park, $20 \mathrm{~km} \mathrm{~N} \mathrm{Jackson} \mathrm{and} \mathrm{about} 5 \mathrm{~km}$ E Moose, Wyoming (Bekoff and Wells, 1980; Wells and Bekoff, 1981). About 50 individuals were observed; 32 animals were fitted with radio collars or colored ear-tags earlier. Observations were made with $20 \times$ spotting scopes or with binoculars; data were recorded on microcassette recorders. Time was measured with digital stopwatches. Data recorded included age, sex, and identity of each coyote; prey species; local wind condition (upwind, downwind, crosswind, and no wind with respect to the relative positions of coyotes and prey); grass height; snow depth; number of acts in the predatory sequence; durations of different acts in sequences including search, orient, stalk, head-thrust, and walk; time elapsed since the last capture was made; prey species last captured; and capture success. Coyote age classifications were: pups (birth-4 months old), juveniles (5-9 months old) and adults (>9 months of age). Because it was not possible to record all information for every observed sequence, sample sizes differed for the analyses reported.

Multivariate techniques (Cooley and Lohnes, 1971) and alpha levels of 0.05 were used. The statistical significance of each two-act transition was analyzed by collapsing transition matrices into $2 \times 2$ tables and performing Chi-square analyses (Rechten and Fernald, 1979). With this procedure, we could determine, for example, whether stalk followed search significantly more or less frequently than would be expected by chance. We also determined the degree of association between corresponding cells in different transition matrices with Spearman rank-order correlation analyses $\left(r_{\mathrm{s}}\right)$ (Bekoff, 1978). The variability of predatory sequences was assessed by calculating coefficients of variation (CV's $=S D / \bar{X})$ for each transition matrix (Bekoff, 1977b, 1978). Coefficients of variation were compared with Sokal and Braumann's (1980) method. Where appropriate, averages are presented as $\bar{X} \pm 1$ SD in text.

\section{PREDATORY ACTS}

The following behavioral patterns constituted major predatory acts. The term "bout" refers to successive sequences directed to the same prey species whereas the term "sequence" refers to the performance of successive acts. Not all acts were necessarily observed in one sequence. Search: Movement that allowed detection of prey not located specifically (Elliott et a!., 1977). Orient: Immobile upright posture facing prey that was located. Stalk: Slow approach at less than normal walking speed toward specifically located prey so that the prey was unaware or undisturbed by predator (Elliott et al., 1977). Coyotes' ears were typically erect, the neck extended forward, and the body lowered slightly. Walk: Same as "stalk" but at a faster pace; predator may be detected. Pounce: Coyote leaped or reared on hindlegs and stabbed at prey with forepaws; pounce may be incorporated into the gait without exaggerated rearing. Rush: Coyote ran down prey without pouncing; acceleration into a rush may follow any act except "pounce." Headthrust: Coyote attempted to grasp prey in mouth with or without pinning it with forepaws. Prey invariably was killed with a crushing bite, often accompanied by side-to-side head-shaking. Consumption usually 
followed immediately, though on some occasions prey was played with before ingestion (Fox, 1969; Vincent and Bekoff, 1978).

\section{RESULTS}

Prey availability and habitat. Field voles and pocket gophers were present throughout the year, although during winter when snow blanketed the study area they were less accessible (Weaver, 1977; Bekoff and Wells, 1981). Uinta ground squirrels were present from mid-April to mid-August and grasshoppers from late June to October. Typically, adults and juveniles hunted voles, only adults hunted gophers and ground squirrels, and only pups sought grasshoppers. Mean bout lengths for successive vole (30 min) and squirrel hunts (26 min) were not significantly different. The main activities of coyotes before hunting were travelling (60.3\% of the time) and resting (28.2\% of the time) (Bekoff and Wells, 1981).

During summer, the field site was sharply differentiated into two "grass types": approximately $4 \mathrm{~km}^{2}$ of $<10 \mathrm{~cm}$-high "short" grass (cropped by cattle) and about $8 \mathrm{~km}^{2}$ of grass up to $1 \mathrm{~m}$ high. Of 294 vole hunts observed when grass length could be assessed reliably, $266(90.5 \%)$ occurred in tall $(>10 \mathrm{~cm})$ grass, whereas only $28(9.5 \%)$ were in short grass (where squirrels mainly lived). Conversely, of 68 squirrel hunts observed in definable habitat, only 2 (2.9\%) occurred in tall grass but 66 (97.1\%) were in short grass. Coyotes usually hunted pocket gophers after snow melt when they were excavated from groundsurface tunnels; all attempts $(n=18)$ occurred in short grass. Grasshoppers were hunted by pups in the vicinity of dens regardless of surrounding grass height; pups did not range far from den sites until they were about 3-4 months old.

TABLE 1. Conditional probabilities for major two-act transitions observed during predatory attempts by coyotes on Uinta ground squirrels and voles in the Grand Teton National Park, Wyoming, September 1977August 1980.

\begin{tabular}{|lcc|}
\hline & \multicolumn{2}{c|}{ Prey } \\
\cline { 2 - 3 } Transition & Uinta ground squirrel & Vole \\
\hline Search-stalk & 0.51 & $0.23^{\star}$ \\
Search-orient & 0.34 & 0.61 \\
Stalk-pounce & 0.01 & 0.26 \\
Stalk-rush & 0.31 & 0.03 \\
Orient-rush & 0.27 & 0.05 \\
Orient-pounce & 0 & 0.26 \\
Rush-head-thrust & 0.46 & $0.59^{\star \star}$ \\
Pounce-head-thrust & 0.75 & $0.56^{\star \star}$ \\
Head-thrust -search & 1.00 & 0.66 \\
\hline
\end{tabular}

* All conditional probability values for squirrels and voles were significantly different $\left[\mathrm{P}<0.001\right.$, proportions test $\left(t_{\mathrm{s}}>\right.$ 4.33), Sokal and Rohlf, 1969].

${ }^{\star *} t_{\mathrm{s}}<1.96, p>0.05$.

Wind conditions. Local wind conditions influenced hunting patterns. When hunting voles, coyotes showed a significant tendency to approach them from downwind $\left(r_{\mathrm{s}}=0.27, \mathrm{n}=458, P<0.001\right)$, probably using olfactory cues to locate hidden animals. When hunting ground squirrels, most of which probably were visible to coyotes, there was no detectable trend among orientation, approach, and wind direction. 
Predatory sequences. Only search occurred in all sequences, and one act could occur more than once during a sequence. Overall, an average of $5.1 \pm 2.8$ acts (range $=2-25, n=530$ ) per hunting attempt was performed. Approximately the same number of acts was used in predatory attempts by adults and juveniles on voles ( $\bar{X}=5.85$ and 4.86 , respectively), by adults on squirrels ( $\bar{X}=4.23$ ), and by pups on grasshoppers $(\overline{\mathrm{X}}=4.37)$. There was no correlation between the number of acts performed in a sequence and age of coyotes $\left(r_{\mathrm{s}}=0.06, \mathrm{n}=530, P<0.09\right)$.

Data concerning frequency with which each of the seven predatory acts followed one another in entire predatory sequences were cast into 7 by 7 transition matrices for adult-vole $(n=240)$, juvenile-vole $(n=$ 125), adult-squirrel $(n=77)$, adult-gopher $(n=17)$, and pup-grasshopper $(n=49)$ encounters, and conditional probabilities were calculated [e.g., $\mathrm{P}(\mathrm{stalk} / \mathrm{search})=$ the probability that stalk occurred next in sequence if search occurred]. There were significant differences between hunting attempts on squirrels and voles (Table 1). For example, stalk followed search significantly more often when ground squirrels were pursued, whereas orient followed search more frequently when voles were hunted. Pouncing was used rarely when squirrels were sought $(n=14,1.2 \%$ of all phases) and rushing was observed infrequently in vole encounters ( $n=44,3.1 \%$ of all phases). Both rush and pounce led to head-thrust with about the same conditional probability in either situation. When squirrels were pursued, head-thrust always terminated a sequence (a new search was initiated), but not when voles were hunted. Thus, if coyotes failed to catch a squirrel, they searched for other prey (usually a squirrel) or stopped hunting.

There was a significant correlation between corresponding cells in matrices that described adult-vole and juvenile-vole predatory encounters $\left(r_{\mathrm{s}}=0.85, z=5.49, P<0.001\right)$; the same two acts occurred in sequence with about the same ranked conditional probability relative to all other pairs of acts (e.g., search-orient, search-stalk, orient-pounce). Adult-vole and adult-squirrel sequences also were similar (search-orient, search-stalk, head-thrust-search), however, overall, they were associated less closely $\left(r_{\mathrm{s}}=\right.$ $0.46, z=3.01, P<0.002)$ than adult-vole and juvenile-vole interactions.

TABLE 2. Relationship between variability and capture success (coefficient of variation, $\mathrm{CV}=\mathrm{SD} / \overline{\mathrm{X}}$ ) of predatory sequences performed in the Grand Teton National Park, Wyoming, September 1977-August 1980, by coyotes of different ages on four different prey types.

\begin{tabular}{|lcccccccc|}
\hline & \multicolumn{7}{c|}{ Coyote age/prey type } \\
\cline { 2 - 8 } Variabilitylsuccess & Pup/grasshopper & & Adult/gopher & & Adult/ground squirrel & Adult/vole & Juvenile/vole \\
\hline CV* $^{*}$ & 5.00 & $>$ & 1.68 & $>$ & 1.56 & $>$ & 1.38 & $=$ \\
Capture success \% & 45 & $<$ & 83 & $>$ & 41 & $>$ & 18 & $=$ \\
\hline
\end{tabular}

* Differences between CV's were analyzed by Sokal and Braumann's (1980) method; the differences among capture success were assessed with proportions tests (Table 1) in conjunction with Snedecor's 11956) method for analyzing the differences among three or more proportions.

Pup-grasshopper sequences were significantly more variable than all others (Table 2). Adult-gopher sequences were more variable than adult-squirrel sequences, and adult-vole and juvenile-vole sequences were equally variable. In all instances, CV's were greater than 1.00 (standard deviations were greater than mean conditional probabilities), indicating that sequences in all categories were highly variable. Excluding pup-grasshopper encounters, increased variability was associated with higher rates of capture (Table 2).

Duration of acts. Durations of search, orient, and stalk and total sequence duration were calculated for hunting attempts that occurred in short and tall grass, in shallow and deep snow, and for different prey (Table 3). Search was the most lengthy component of hunting attempts and was correlated highly with 
total sequence duration $\left(r_{\mathrm{s}}=0.90, \mathrm{n}=173, P<0.001\right)$. Overall, mean durations (s) for different acts were: search, $125.3 \pm 118.6$ (range, 6-624); orient, $46.7 \pm 85.2$ (2-900); stalk, $31.9 \pm 77.3$ (1-669); total, $192.6 \pm$ 162.5 (11-1026).

General step-wise multiple regression analyses showed that grass height accounted for the greatest proportion of variability in duration of search $(P=0.05)$, orient $(P=0.02)$, and total sequence length $(P=$ 0.009 ), and accounted for the second largest proportion (though not significant; $P=0.06$ ) of variability in stalk duration. The habitat in which hunts occurred and prey type also affected act durations (Table 3). Mean durations of search, orient, and stalk were significantly longer in short grass, whereas total duration was about the same in both short and tall grass. Snow depth also influenced act durations for vole hunts; all acts, including mean total sequence length, were significantly longer in deep snow. Search durations were about equal, but significantly longer, when squirrels and gophers were hunted than when voles and grasshoppers were sought, but orient durations were similar regardless of prey. Mean stalk duration was longest for squirrels and about the same for the three other prey species. Encounters with squirrels were significantly longer than attempts on gophers, mice, or grasshoppers. Because squirrels typically were hunted in short grass, longer durations were expected. Although voles usually were hunted in tall grass, mean search duration (short grass, $\overline{\mathrm{X}}=175.2 \pm 134.5 \mathrm{~s}$; tall grass, $\overline{\mathrm{X}}=107.6 \pm 94.3 \mathrm{~s}, F=5.5$, d.f. $=1$, $136, P=0.02)$, orient duration $(\overline{\mathrm{X}}=82.4 \pm 112.05 \mathrm{~s}$ and $\overline{\mathrm{X}}=34.1 \pm 33.5 \mathrm{~s}, F=9.0$, d.f. $=1,80, P=0.004)$, and total sequence duration $(\overline{\mathrm{X}}=268.0 \pm 188.9 \mathrm{~s}$ and $\overline{\mathrm{X}}=181.3 \pm 121.9 \mathrm{~s}, F=7.4$, d.f. $=1,74, P<0.02)$ also were significantly greater when they were hunted in short grass, indicating the importance of grass height in influencing the duration of specific acts. Mean stalk duration (14 s) was the same in short and tall grass $(F=0.01$, d.f. $=1,43, P=0.93)$.

Wind direction had little effect on mean durations of different acts. Length of hunting acts was about the same in all wind conditions with the exception of search, which was significantly longer when there was a crosswind between coyotes and prey. Mean length of pup sequences was significantly shorter $(\overline{\mathrm{X}}=97.2 \pm$ $76.7 \mathrm{~s})$ than that of adults $(212.6 \pm 183.9 \mathrm{~s})$ or juveniles $(201.3 \pm 130.7 \mathrm{~s} ; F=5.6$, d.f. $=2,176, P=$ 0.004); those of juveniles and adults lasted about the same amount of time. Mean durations of search, orient, and stalk were unaffected by age.

The variability of act durations (CV's calculated from data in Table 3) generally was associated with habitat, prey type, wind conditions, and capture success. Stalk, orient, and total durations were significantly more variable in short grass than in high grass but search duration was about equally variable in both habitats. Mean orient and total durations were significantly more variable in deep snow than in shallow snow, whereas mean search and stalk durations were equally variable in both conditions. Stalking was significantly more variable when ground squirrels were hunted than when voles were sought. However, orient was more variable during encounters with voles. The variability of search durations was about the same for squirrels and voles. Greatest levels of variability in search, stalk, and total durations occurred when there was no wind but the least amount of variability always occurred (for search, orient, stalk, and total durations) when coyotes approached prey from downwind. Only the variability of mean stalk durations was associated with capture success; stalking was significantly more variable during successful hunts $(C V=2.4)$ than during unsuccessful ones $(C V=1.5)$.

Capture success. Discriminant function analysis was used to assess the relative influence of age, prey species, wind direction, grass height, and snow depth on capture success. Although short grass had the highest standardized discriminant coefficient (0.73), all variables combined could not reliably discriminate successful from unsuccessful attempts; only 387 (73\%) of 530 sequences were classified correctly. 
TABLE 3. Mean \pm 1 standard deviation of durations (in seconds) of three predatory acts and total sequence length in different habitats (short and tall grass; shallow and deep snow) and for coyotes encountering four different prey types, Grand Teton National Park, Wyoming, September 1977-August 1980. Only vole hunts were used in the snow analyses. Means were compared by use of analyses of variance (ANOVA's) and Scheffé procedures.

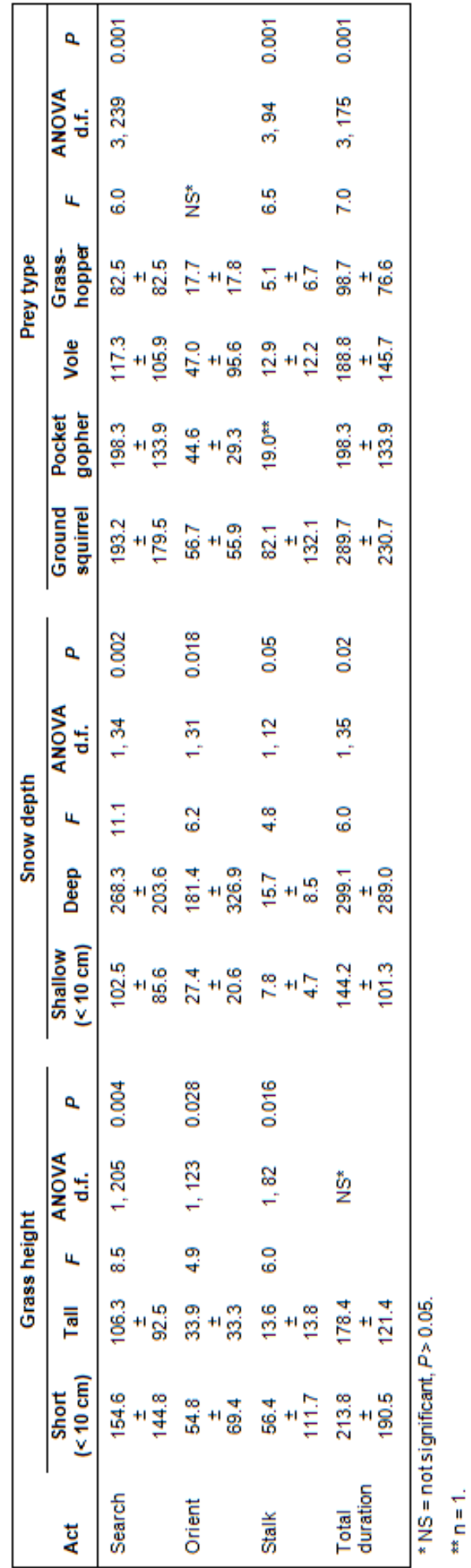


TABLE 4. Relationships between mean capture success and age of coyotes, prey species, wind direction, grass height, and snow depth. Observations were made in the Grand Teton National Park, Wyoming, September 1977-August 1980 . Means were compared by use of analyses of variance (ANOVA's) and Scheffé procedures.

\begin{tabular}{|c|c|c|c|c|c|}
\hline & \multirow[b]{2}{*}{ Variable } & \multirow[b]{2}{*}{ Mean capture success \% } & \multicolumn{3}{|c|}{ ANOVA } \\
\hline & & & $\boldsymbol{F}$ & d.f. & $\boldsymbol{P}$ \\
\hline Age & $\begin{array}{l}\text { Pup }(N=49) \\
\text { Adult }(N=348) \\
\text { Juvenile }(N=133)\end{array}$ & $\begin{array}{l}45 \\
27 \\
18\end{array}$ & 6.9 & 2,527 & $<0.001$ \\
\hline Prey type & $\begin{array}{l}\text { Pocket gopher }(\mathrm{N}=18) \\
\text { Grasshopper }(\mathrm{N}=50) \\
\text { Ground squirrel }(\mathrm{N}=68) \\
\text { Vole }(\mathrm{N}=394)\end{array}$ & $\begin{array}{l}83 \\
54 \\
41 \\
18\end{array}$ & 27.3 & 3,526 & $<0.001$ \\
\hline Wind direction * & $\begin{array}{l}\text { Downwind }(N=41) \\
\text { Crosswind }(N=45) \\
\text { Upwind }(N=115) \\
\text { No wind }(N=239)\end{array}$ & $\begin{array}{l}41 \\
27 \\
22 \\
22\end{array}$ & 2.6 & 3,436 & $>0.05$ \\
\hline Grass height & $\begin{array}{l}\text { Short }(<10 \mathrm{~cm} ; N=45) \\
\text { Tall }(N=275)\end{array}$ & $\begin{array}{l}48 \\
16\end{array}$ & 58.3 & 1,434 & $<0.001$ \\
\hline Snow depth & $\begin{array}{l}\text { Shallow }(<10 \mathrm{~cm} ; N=45) \\
\text { Deep }(N=49)\end{array}$ & $\begin{array}{c}21 \\
8\end{array}$ & 7.2 & 1,92 & $<0.009$ \\
\hline
\end{tabular}

* Downwind means prey was downwind from the coyote (coyote approached prey from upwind direction).

Analyses of variance were used to examine the influence of each variable on capture success (Table 4). Pups were more successful than older coyotes (pups hunted only grasshoppers). Adults and juveniles were about equally successful. Coyotes were most successful when hunting gophers and least successful hunting voles. Wind direction did not influence success. Coyotes were significantly more successful hunting in short grass and shallow snow. Although voles typically were hunted in tall grass, coyotes were significantly more successful when hunting them in short grass (42.1\%; success in high grass $\left.=15.0 \% ; t_{\mathrm{s}}=3.56, P<0.001\right)$. Only duration of stalking was related to hunting success. Mean stalk duration of successful predatory attempts was significantly longer and more variable $(54.3 \pm 127.9 \mathrm{~s})$ than for unsuccessful attempts $(21.6 \pm 31.6 \mathrm{~s} ; F=3.9$, d.f. $=1,96, P<0.05)$. Lastly, duration of the interval since the last observed capture was not correlated with the outcome of the next predatory attempt $\left(r_{s}=\right.$ $0.09, \mathrm{n}=117, P=0.18$ ).

Prey size and subsequent searches. The size of prey last eaten influenced the length of the interval to initiation of the next search by an individual coyote; as prey size increased, there was a longer interval to the next search $\left(r_{s}=0.42, t=2.71\right.$, d.f. $\left.=34, P<0.01\right)$. For the analysis, we used mean weight of voles to be about $25 \mathrm{gm}$, gophers about $70 \mathrm{gm}$, and squirrels about $200 \mathrm{gm}$ based on approximate relative representation of different-aged prey eaten by coyotes in the vicinity of our study area (Weaver, 1977). We found that when voles were eaten last, the mean interval to initiation of the next search was $103.0 \mathrm{~s}$, when gophers were eaten last, it was $339.0 \mathrm{~s}$, and when squirrels were eaten last, the interval was 607.3 $\mathrm{s}$. These mean values all differed from one another (Kruskal-Wallis one-way analysis of variance by ranks, $\mathrm{H}=6.33$, d.f. $=2, P<0.05$ ). The regression equation for this relationship was $\mathrm{y}=57.61+2.88 \mathrm{x}$ $(x=$ prey weight, $y=$ interval until next search initiated). The coefficient of determination (Sokal and Rohlf, 1969), $r^{2}=0.19$, indicated that factors other than prey size also influenced this relationship. 


\section{DISCUSSION}

Our results show that understanding predatory behavior of wild coyotes requires consideration of at least the types of prey available, the habitat in which prey are sought, wind conditions, and age of the coyote. Analyses of the ways these variables influence predation both singly and in combination provides insight into the "sensory ecology" (Suthers, 1978) of a species. Internal factors such as hunger also must be considered in studies of predation (Hinde, 1970; Curio, 1976), but in field studies these variables are difficult to control and to analyze rigorously. For example, the relationship between size of prey eaten last and the interval to initiation of the next search (the larger the prey, the longer the interval) (Elliott et al., 1977) probably was related to a combination of reduced hunger, increased feeding time, and perhaps differential digestibility of different prey (Litvaitis and Mautz, 1980; Meriwether and Johnson, 1980). However, hunger (as measured by the time since the last meal) did not affect capture success (Jansen, 1974; Vincent and Bekoff, 1978). Therefore, satiation seemed to retard searching but not catching and killing. Leyhausen (1965) and Kruuk (1972b) suggested that in carnivores catching and killing were distinct motivationally from searching.

Predatory sequences and acts: variability and length. The ability to alter a response with environmental changes (different stimuli) is an adaptive skill, and is well developed in carnivore predatory behavior (Leyhausen, 1965; Ewer, 1968; Eisenberg and Leyhausen, 1972). In part, variability in the behavior of a predator depends on the nature of the prey (Eisenberg and Leyhausen, 1972). Coyotes adjusted their behavior according to prey size; ground squirrels were rushed and pursued but relatively smaller voles were pounced upon and pinned with the forepaws. Variability and success were related; adult coyotes were most successful when the sequencing of predatory acts was most variable. Also mean stalk duration for successful predatory sequences was significantly longer and more variable than for unsuccessful attempts.

Habitat also affected predatory behavior. When there were significant differences in the variability of the durations of predatory acts in different grass habitats, variability was greater in short grass, where success was higher. Mean durations of search, orient, and stalk were greatest in short grass and deep snow (total sequence length also was longer in deep snow than with thin snow cover). In deep snow, coyote mobility and detection of buried prey were reduced. Indeed, hunting activities were curtailed when deep snow covered the study area during winter, and ungulate carrion was available (Bekoff and Wells, 1981). Greater variability in durations of orient and total sequence length in deep snow may be explained by the fact that "deep snow" ranged in depth from about $10 \mathrm{~cm}$ to $1 \mathrm{~m}$. Palm (cited in Curio, 1976, p. 197) observed that red foxes (Vulpes vulpes) were less successful hunting mice in deep snow than in shallow snow.

Environmental influences on capture success. Habitat exerted the major influence on predatory success; coyotes were most successful when they hunted in short grass and shallow snow. The short grass area inhabited by ground squirrels seemed to influence capture rate the most. When voles were hunted in short grass (mainly in spring), they too were caught more frequently than when they were hunted in tall grass.

Habitat may influence predatory behavior by affecting the way sensory cues from prey are transmitted to predators and by influencing predator detection by prey. The short grass habitat allowed us and probably the coyotes to detect ground squirrels. Although the visual acuity of coyotes is unknown, the overall structure of their eyes is not much different from those of Homo sapiens (Horn and Lehner, 1975). Vision is relied on heavily by coyotes that hunt rabbits (Wells, 1978; Wells and Lehner, 1978). The use of visual cues when hunting ground squirrels was suggested by the lack of influence of wind on predatory behavior when coyotes hunted in short grass. In an experiment with captive animals, wind direction did not 
influence coyotes hunting rabbits when they were able to see them (Wells, 1978). Tall grass possibly excluded the use of vision until coyotes were very close to their prey; coyotes tended to approach voles in high grass from downwind, indicating use of airborne (olfactory) stimuli. The same trend was noted when captive coyotes were allowed to use only olfaction when they hunted rabbits (Wells, 1978).

Wind did not directly affect capture success, suggesting that coyotes used wind when available, but it was not needed to locate prey obscured from sight. This contradicts experimental results where captive coyotes had great difficulty locating invisible prey in absence of wind (Wells and Lehner, 1978). Absence of wind was associated with greater variability in the durations of search, stalk, and total sequence length, suggesting that coyotes possibly adjusted to various prey stimuli by switching between olfaction and audition to complement visual input.

Coyotes made use of both visual and olfactory stimuli, with higher hunting success when visual stimuli were present. Other predators similarly employ their senses to varying degrees, depending on sensory capabilities and available stimuli (Ewer, 1973). For instance, red foxes (Vulpes vulpes) detect a wide range of auditory stimuli (Peterson et al., 1969), can localize sources of sound over a large range (Isley and Gysel, 1975), and seem to rely mostly on auditory cues when hunting (Österholm, 1964). These sensory priorities correlate well with the nocturnal habits of red foxes (Storm, 1965; Ables, 1969) and their reliance on small mammals for food (Ables, 1975). Mills (1978) noted that brown hyaenas (Hyaena brunnea) moved upwind to food and seemed to depend mainly on olfaction when foraging. This dependence on olfactory cues probably is related to their nocturnal habits and their dependence on carrion for food. Lions (Panthera leo) apparently rely on their senses in the order of vision, audition, and olfaction when hunting (Schaller, 1972), and, although they often hunt nocturnally (Elliott et al., 1977), they do not seem to heed wind direction (Schaller, 1972; Elliott et al., 1977).

Habitat also may influence detection of predators by prey. Ground squirrels undoubtedly were able to see coyotes over long distances. Thus, searching for ground squirrels by coyotes probably involved not so much detection of hidden prey as simply finding vulnerable individuals, which might account for the relatively longer mean search duration during ground squirrel hunts. Because evasive behavior by squirrels involved running to obvious burrows, coyotes seemed to assess the situation then try to reduce the ratio of predator-prey/prey-hole distance. As with lions who also overtake their prey (Elliott et al., 1977), stalking duration was the most important variable influencing hunting success. Indeed, coyotes stalked squirrels significantly longer than other prey.

Definable factors exerted major influences on predatory behavior of free-ranging coyotes. Similar data for coyotes living in other habitats and information for other carnivores are needed for comparative analyses and general syntheses.

\section{ACKNOWLEDGMENTS}

This study was supported by grants from the NIMH (29571), NSF (BNS-78-27616 and BNS-79-23463), and the Harry Frank Guggenheim Foundation, and by a Faculty Fellowship from the University of Colorado and a John Simon Guggenheim Memorial Foundation Fellowship to M.B. The administrators of the Grand Teton National Park graciously allowed us to continue our studies within park boundaries. M. C. Grant provided invaluable assistance with statistical analyses and P. Holman typed the manuscript. Two reviewers provided valuable comments. B. Jansen and A. Rathbun helped substantially with observations. 


\section{LITERATURE CITED}

ABLES, E. D. 1969. Activity studies of red foxes in southern Wisconsin. J. Wildl. Mgmt., 33:145-153.

---. 1975. Ecology of the red fox in America. pp. 216-236, in The wild canids (M. W. Fox, ed.). Van Nostrand, New York, 508 pp.

BEKOFF, M. 1977a. Canis tatrans Say 1823. Mamm. Species, 79:1-9.

---. 1977b. Quantitative studies of three areas of classical ethology: social dominance, behavioral taxonomy, and behavioral variability. pp. 1-46, in Quantitative methods in the study of animal behavior (B. A. Hazlett, ed.). Acad. Press, New York, 222 pp.

---. 1978. A field study of the development of behavior in Adelie penguins: univariate and numerical taxonomic approaches. Pp. 177-202, in The development of behavior: comparative and evolutionary aspects (G. Burghardt and M. Bekoff, eds.). Garland, New York, 429 pp.

BEKOFF, M., AND M. C. WELLS. 1980. The social ecology of coyotes. Sci. Amer., 242:130-148.

--- 1981. Behavioural budgeting by wild coyotes: the influence of food resources and social organisation. Anim. Behav., 29:794-801.

COOLEY, W. W., AND P. R. LOHNES. 1971. Multivariate data analysis. J. Wiley and Sons, New York, $364 \mathrm{pp}$.

CURIO, E. 1976. The ethology of predation. Springer-Verlag, Berlin and New York, 250 pp.

DUNSTONE, N., AND R. J. O'CONNOR. 1979a. Optimal foraging in an amphibious mammal. I. The aqualung effect. Anim. Behav., 27:1182-1194.

---. 1979b. Optimal foraging in an amphibious mammal. II. A study using principal component analysis. Anim. Behav. 27:1195-1201.

EISENBERG, J. F., AND P. LEYHAUSEN. 1972. The phylogenesis of predatory behavior in mammals. $Z$. Tierpsychol., 30:59-93.

ELLIOTT, J. P., I. MCTAGGART COWEN, AND C. S. HOLLING. 1977. Prey capture by the African lion. Canadian J. Zool., 55:1811-1828.

ESTES, R. D., AND J. GODDARD. 1967. Prey selection and hunting behavior of the African wild dog. J. Wildl. Mgmt., 31:52-70.

EWER, R. F. 1968. The ethology of mammals. Plenum, New York, 418 pp.

---. 1973. The carnivores. Cornell Univ. Press, Ithaca, New York, 494 pp.

FOX, M. W. 1969. Ontogeny of prey-killing behavior in Canidae. Behaviour, 35:259-272.

GIBB, J. A. 1962. L. Tinbergen's hypothesis on the role of specific search images. Ibis, 104:106-111.

GIER, H. T. 1968. Coyotes in Kansas. Kansas State College Agric. Appl. Sci. Bull., 393:1-118.

HENRY, J. D. 1980. Fox hunting. Nat. Hist., 89:61-69.

HINDE, R. A. 1970. Animal behaviour. Seconded. McGraw-Hill, New York, 876 pp.

HOLLING, C. S. 1965. The functional response of predators to prey density and its role in mimicry and population regulation. Mem. Entomol. Soc. Canada, 45:1-60.

---. 1966. The functional response of invertebrate predators to prey density. Mem. Entomol. Soc. Canada, 48:1-86.

HORN, S. W., AND P. N. LEHNER. 1975. Scotopic sensitivity in the coyote (Canis latrans). J. Comp. Physiol. Psychol., 89:1070-1076.

ISLEY, T. E., AND L. W. GYSEL. 1975. Sound-source localization by the red fox. J. Mamm., 56:397-404.

JANSEN, C. D. 1974. Behavior patterns observed in coyote-sheep interactions. Unpubl. M.S. thesis, Colorado State Univ., Fort Collins, $57 \mathrm{pp}$.

KAMIL, A. C., AND T. D. SARGENT (eds.). 1981. Foraging behavior: ecological, ethological and psychological approaches. Garland, New York. 534 pp.

KREBS, J. R. 1973. Behavioural aspects of predation. pp. 73-111, in Perspectives in ethology (P. P. G. Bateson and P. H. Klopfer, eds.). Plenum Press, New York, 336 pp. 
KRUUK, H. 1972a. The spotted hyaena. A study of predation and social behavior. Univ. Chicago Press, Chicago, $335 \mathrm{pp}$.

---. 1972b. Surplus killing by carnivores. J. Zool. London, 166:233-344.

---. 1978. Foraging and spatial organisation of the European badger, Metes metes L. Behav. Ecol. Sociobiol., 4:75-89.

LEYHAUSEN, P. 1965. Uber die Funktion der relative Stimmunghierarchie (dargestellt am Biespiel der phylogenetischen und ontogenetischen Entwicklung des Beutefangs von Raubtieren). Z. Tierpsychol., 22:412-494.

LITVAITIS, J. A., AND W. W. MAUTZ. 1980. Food and energy use by captive coyotes. J. Wildl. Mgmt., 44:56-61.

MACCONNELL-YOUNT, E., AND C. SMITH. 1978. Mule deer-coyote interactions in north-central Colorado. J. Mamm., 59:422-423.

MACDONALD, D. W. 1980. The red fox, Vutpes vutpes, as a predator upon earthworms, Lumbricus terrestris. Z. Tierpsychol., 32:171-200.

$\mathrm{MECH}$, L. D. 1970. The wolf: the ecology and behavior of an endangered species. Nat. Hist. Press, Garden City, New York, 384 pp.

MERIWETHER, D., AND M. K. JOHNSON. 1980. Mammalian prey digestibility by coyotes. J. Mamm., 61:774-775.

MILLS, M. G. L. 1978. Foraging behaviour of the brown hyaena (Hyaena brunnea Thunberg, 1820) in the southern Kalahari. Z. Tierpsychol., 48:113-141.

MORSE, D. H. 1980. Behavioral mechanisms in ecology. Harvard Univ. Press, Massachusetts, 383 pp.

MURIE, A. 1940. Ecology of the coyote in the Yellowstone. Fauna Nat. Parks Ser., 4:1-206.

MURIE, O. J. 1951. The elk of North America. Wildl. Mgmt. Instit., Washington, DC, 376 pp.

ÖSTERHOLM, H. 1964. The significance of the distance receptors in the feeding behaviour of the red fox Vutpes vutpes L. Acta. Zool. Fenn., 106:1-31.

PETERSON, E. A., W. C. HEATON, AND S. D. WRUBLE. 1969. Levels of auditory response in fissiped carnivores. J. Mamm., 50:566-578.

RECHTEN, C., AND R. D. FERNALD. 1979. A sampled randomization test for examining single cells of behavioural transition matrices. Behaviour, 69:215-227.

RASA, O. A. E. 1973. Prey capture, feeding techniques, and their ontogeny in the African dwarf mongoose, Helogale undulata rufula. Z. Tierpsychol., 32:449-448.

ROWE-ROWE, D. T. 1978. Comparative prey capture and food studies of South African mustelines. Mammalia, 42:175-196.

SCHALLER, G. B. 1972. The Serengeti lion. A study of predator-prey relations. Univ. Chicago Press, Chicago, $480 \mathrm{pp}$.

SCHOENER, T. W. 1971. Theory of feeding strategies. Ann. Rev. Ecol. Syst., 2:369-404.

SNEDECOR, G. W. 1956. Statistical methods. lowa State College Press, Ames, lowa, 534 pp.

SOKAL, R. R., AND C. A. BRAUMANN. 1980. Significance tests for coefficients of variation and variability profiles. Syst. Zool., 29:50--66.

SOKAL, R. R., AND J. L. ROHLF. 1969. Biometry. Freeman, San Francisco, California, 776 pp.

STORM, G. L. 1965. Movements and activities of foxes as determined by radio-tracking. J. Wildl. Mgmt., 29:1-13.

SUTHERS, R. A. 1978. Sensory ecology of mammals. pp. 253-287, in Sensory ecology: review and perspectives (M. A. Ali, ed.). Plenum Press, New York, 607 pp.

TINBERGEN, L. 1960. The natural control of insects in pine woods. I. Factors influencing the intensity of predation by songbirds. Arch. Neerl. Zool., 13:265-343.

TRUETT, J. C. 1979. Observations of coyote predation on mule deer fawns in Arizona. J. Wildl. Mgmt., 43:956-958. 
VINCENT, L. E., AND M. BEKOFF. 1978. Quantitative analyses of the ontogeny of predatory behavior in coyotes, Canis latrans. Anim. Behav., 26:225-231.

WEAVER, J. L. 1977. Coyote-food base relationships in Jackson Hole, Wyoming. Unpubl. M.S. thesis, Utah State Univ., $88 \mathrm{pp}$.

WELLS, M. C. 1978. Coyote senses in predation: environmental influences on their relative use. Behav. Proc., 3:149-158.

WELLS, M. C., AND M. BEKOFF. 1981. An observational study of scent marking in free-ranging coyotes. Anim. Behav., 29:332-350.

WELLS, M. C., AND P. N. LEHNER. 1978. The relative importance of the distance senses in coyote predatory behaviour. Anim. Behav., 26:251-258.

YOUNG, S. P., AND H. H. T. JACKSON. 1951. The clever coyote. Stackpole, Harrisburg, Pennsylvania, $411 \mathrm{pp}$. 